\title{
2
}

\section{German-language anthropology traditions around 1900: Their methodological relevance for ethnographers in Australia and beyond}

\author{
André Gingrich
}

This overview will outline the main chapters of anthropology's development in German before 1900 and thereafter, while paying special attention to the connections to and interactions with respective ethnographic research in Australia. ${ }^{1}$ The general rationale of this examination is therefore to explore which intellectual and methodological inspirations emerged inside the history of anthropology in German throughout the nineteenth and early twentieth centuries in such a way that they directly or indirectly inspired ethnographically relevant research that was carried out in Australia while being written up in German.

1 The author wishes to acknowledge with gratitude the substantial academic discussions that have helped to improve this chapter: first, by Nic Peterson and Anna Kenny (both in Canberra), as this volume's editors as well as academic hosts to the conference that preceded it; second, by Gabriele Weichart and Peter Schweitzer (both in Vienna); third, by the publishing house's anonymous reviewers. My special thanks go to Eva-Maria Knoll (Vienna) for elaborating Figures 2.1, 2.2, 2.3 and 2.4, which accompany this text. 
There are general and particular dimensions to this task. One of the more general challenges lies in presenting, in a humble and modest manner, elements of an overview on the main phases and connections of anthropology in German before and after 1900 while experts continue to investigate that history. If such a provisional overview on anthropology in German is the more general side of my topic, my special attention will attempt to focus on how that 'general' dimension intersected with the 'particular' challenges of ethnography and anthropology in Australia while it was in the making during those decades, with specific attention to those sources that were written in German. I shall strive to address this specific interplay between the general 'anthropology in German' topic and the particular challenges of the 'ethnographic Australian sources in German' side through three short sections followed by a conclusion.

The first section will focus on legacies before 1850 that continued to profoundly shape anthropology in German by the mid-nineteenth century - that is, when German-speaking explorers had entered the scene and while missionaries began to come to Australia in somewhat larger numbers and stayed on for longer periods. I will start with a short review of those legacies from the Enlightenment and Romanticist periods that continued to have an impact in the 1850s and beyond. I will then move on to discuss the early phases of German-speaking anthropology's institutionalisation between the 1850s and the last decades of that century. This will help us to identify a fairly coherent conceptual frame of reference that became quite relevant for most ethnographically active people in Australia with a German-speaking background. That conceptual frame of reference was informed by elements of those earlier Romanticist legacies, but also by the more recent requirements of institutional museum life. Section three then follows up by discussing my core topic, the 'main conceptual trajectories before and after 1900', by demonstrating how that conceptual frame of reference differentiated into the main so-called schools of German-speaking anthropology in their dimensions of some relevance for Australia. Finally, my conclusions will address continuities and discontinuities in this regard after World War I through the theme of 'transitions'.

My approach is oriented according to historical phases and sequences, as I think is befitting for historians of anthropology and, also, for historical anthropologists. Beyond that, I will pay somewhat closer attention to the histories of ideas and methods, rather than to those of institutions 
or individual biographies, and I shall follow a general observance of transnational and postcolonial interests into the field's historical trajectories. It is to be mentioned merely in passing that a German nationstate was founded as late as 1871 . Regina Ganter has made this point abundantly clear on her websites and in her other published texts. I shall follow her example and carefully avoid any late-nationalist terminology, so the term 'German-speaking' and corresponding equivalents will provide my general frame of reference in this regard.

\section{Earlier legacies by 1850}

Most scholars of the history of anthropology in German agree about especially long intellectual trajectories of relevance that preceded those subsequent phases of increasing institutionalisation that were setting in after $1850 .{ }^{2}$ Regarding the content of those long precursor trajectories, most experts also seem to agree, by and large, on two additional basic points. Those earlier intellectual trajectories had received decisive impulses and orientations at the turn of the nineteenth century-that is, first, from the late and unfinished philosophical Enlightenment era in German; and second, from early Romanticist academic interests in philology, languages, literature and art traditions. In short, it has come to be an accepted insight today about a global understanding of the history of anthropology that one of its main roots can be identified in Germanspeaking Enlightenment and early Romanticism (Figure 2.1).

Johann Forster and his son, Georg (especially after accompanying James Cook on his second voyage), Johann Gottfried Herder in his critical interaction with Immanuel Kant and the von Humboldt brothers, Alexander and Wilhelm, represented the key authors and influences in this enduring intellectual scenario-with Adelbert von Chamisso and many others as less influential but contributing players who should not be ignored.

2 For some of the central studies in English of the history of German-language anthropology during the main periods under scrutiny here, see Brandewie (1990); Gingrich (2005); Johler et al. (2010); Penny and Bunzl (2003); Vermeulen (2015); Zammito (2002). 


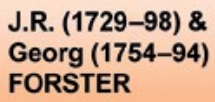

LATE ENLIGHTENMENT THOUGHT

$$
\begin{aligned}
& \text { Immanuel } \\
& \text { KANT } \\
& \text { (1724-1804) }
\end{aligned}
$$

\section{Johann G.}

HERDER

(1744-1803)
Alexander (1769-1859)

\&. Wilhelm (1767-1835)

v. HUMBOLDT

Figure 2.1 Key influences in late Enlightenment and early Romantic movement thought.

Source: A. Gingrich and E. M. Knoll.

In my view, that scenario may be best understood through the lasting intellectual and methodological impact it exerted on the humanities in German. That impact may be addressed in a balanced way as the productive and unstable tension between universalism and relativism as modalities of investigating human lives and human relations. Kant and the Forsters were more explicitly on the universalist side of that tension, which is one among several reasons they upheld some expectations concerning the relevance of biological factors that included their occasional but systematic reference to notions of race. Parallel with that, Johann F. Blumenbach elaborated on biological paradigms of the first universalist classification of hierarchical human races that represented those of dark skin colour as the lowest level. It seems that some early German travellers with training in biology or medicine already were at least partially influenced by that universalist and natural sciences part of the spectrum, as indicated in Hermann Koeler's reports on South Australia from 1837 to 1838 .

By contrast, Herder and the von Humboldt brothers put a much stronger emphasis on the notion of 'unity through diversity' and saw little need for integrating ideas about race into that. So Herder and the Humboldt brothers did pursue some early versions of a 'relativist' or 'weak' universalism that indeed has remained relevant for the main subsequent trends in German-speaking, but also North American, anthropology, as we know through the biographies of Franz Boas, Robert Lowie and Alfred Kroeber. 
In spite of significant epistemological differences between late Enlightenment and early Romanticist thinkers in German, it would be quite one-sided if we emphasised beyond proportion only the differences between them. This is why a friendly caveat is in place here. As a Protestant theologian, Herder believed not only in humanity's unity by creation, but also in its mission towards improvement. It therefore would be inappropriate to characterise him as an 'anti-evolutionist' before the term. In fact, some of Herder's writing can be easily read as if he was sympathising with a tree or a bush model of multiple evolution rather than with a staircase model of unilinear progress upward. Having emphasised this point of general agreement among most Herder experts, I would like to add that neither the Humboldts' nor Herder's work should be idealised. Although they refrained from constructing any racial hierarchies, their universalist relativism was not an egalitarian one. The hierarchies they attributed to relations among large groups of humans were not of a racial but of a cultural kind.

The most significant early connection between the Herder-Humboldt strand of reasoning in the German-language zone and research in Australia is featured in the work of Friedrich W. L. Leichhardt (1813-48), who famously disappeared (presumed perished) with his team in Central Australia during the third of his expeditions. Although hardly appreciated in Europe, Leichhardt's biography and legacy are well known in Australia, and his scholarly diaries have been made available recently in a fine translation (Darragh and Fensham 2013). They demonstrate quite clearly that this geographer and biologist also had a keen interest in Aboriginal matters, and how the Humboldts indeed served as intellectual role models for the pursuit of his expeditions.

Another important connection between scientific reasoning in German during the mid-nineteenth century and research in Australia was established by the Imperial Austrian Novara frigate's expedition during the 1850s (in fact, preparations for this first circumnavigation of the world by a German-speaking crew and captain had begun during the 1840s). That expedition also included sojourns by expedition members in New South Wales and Victoria in 1858-59. While the expedition's medical members carried out some case examples of physical measurements among Aboriginal groups and also collected human remains, Carl von Scherzer was responsible for a fairly broad and systematic linguistic and ethnographic survey. The results of these investigations were published during the 1860 s as part of the expedition's results in 
20 volumes, with Friedrich Müller as responsible author for the volumes on ethnography and linguistics $(1867,1868)$. The expedition's general orientation was positioned within the wide and contradictory tension between the legacies of late Enlightenment and colonial Romanticism and racism. Müller, who never would visit Australia himself, was able to integrate von Scherzer's linguistic material into his first attempt towards a systematic overview of linguistic diversity in Australia ${ }^{3}$ and elsewhere, which he would then try to correlate with a specific version of racial classification. In this manner, Müller represented a good example of those in the German-speaking humanities who tried to combine Humboldtian relativism with the emerging racism in the biological and medical fields. Müller eventually became an influential founding figure for linguistic ethnography in Vienna and beyond, by further elaborating this often overlooked collection of Aboriginal linguistic material as an element in his treatise (Müller 2004) on linguistic diversity and racial hierarchies.

The Humboldts had been fairly close to an early form of linguistic relativism (as elaborated much later by Sapir and Whorf), but the basic differences they had seen between various groups of languages also included what they understood as different levels of potential linguistic (and mental) sophistication. For Herder, by contrast, the main cultural differentiation beyond the particular originated with the absence or presence of writing, and of the state. This led to his influential and fateful distinction between 'natural' and 'cultural' peoples-and it is easy to envision where this particularly popular, nineteenth-century classification in German would situate Australian Aborigines. It is true that distinguishing 'Naturvölker' from 'Kulturvölker' became fetishised by later followers of Herder in ways that were alien to him, yet the distinction per se did already feature quite prominently in his own work-together with his valuable emphasis on songs, proverbs and myths as the collective 'soul' of a people to be explored and expressed through language.

All of this may be fairly well known, but, in a volume on the Germanlanguage tradition's influence on Australian anthropology for which Herder and the Humboldts were in fact quite important, the integration of a balanced perspective on these authors and their influence is indispensable. With all due appreciation for their productive legacies, it would be misleading to morally classify them as more 'positive' in

3 I am indebted to Stefan Sienell (Archives of the Austrian Academy of Sciences) and to Clara Stockigt (Department of Linguistics, University of Adelaide) for helping me to establish these points. 
contrast with others - for example, those working in the British traditions. Those lines of tradition were more dominant and more continuous, and this more marginalised and more frequently interrupted sequence in German certainly had alternative merits in its own right, but it also featured a number of substantial biases and specific shortcomings.

This also concerns an open debate rather than the more established insights as addressed so far. The notions of humanity and humanism have caused some discussions with regard to the history of anthropology in German and, as I see it, some confusion. I consider one of these two terms as being quite clear-namely, humanity in its German-language meaning since the early nineteenth century, that is Menschheit. In fact, Australia played some role in this notion; after all, since the 1810s and 1820s, it had dawned on German-speaking thinkers that, in an empirical sense, it could be taken for granted that all the continents inhabited by humans were now known. So, in a positive and affirmative way, knowledge of Australia sealed and completed the acknowledgement of a globally existing humanity. Humanism, by contrast, is a contested term in its German version (Humanismus) without any clear philosophical qualities. I remain fairly sceptical of the validity and usefulness of this term for understanding the history of research in nineteenth-century German-speaking academia in general. For anthropology, in particular, we might not even need that term at all. It designates two very different movements that had very little to do with each other. First, an early humanism of the fifteenth and sixteenth centuries-basically, the philosophical side of the Renaissance, emanating from Italy and culminating with Erasmus of Rotterdam's work, but having limited impact in the German lands. Second, about 300 years later, neo-humanism emerged in its German version-namely, as an educational ideal to be instrumentalised for the aspiration of nationbuilding processes towards a unified German state. Neo-humanism implied a certain obsession with antiquity as one of two alleged roots of German nationhood (Nordic culture was seen as the second of these two roots). In short, I suspect that the so-called humanist tradition is an artificial and fictional invention by liberal German nationalism seeking to invent a 'longue durée' where there never was any, by combining neo-humanism of the nineteenth century with Renaissance thought of the fifteenth and sixteenth centuries. I thus do not really see how neohumanism, with its preoccupation for Mediterranean antiquity, could have been important to anthropology in German, as some authors have claimed. It is quite sufficient to understand that, by the 1850s, Germanspeaking explorers, most missionaries and early ethnographers agreed that 
indigenous peoples in remote areas such as Australia were basically part of humanity, although they usually regarded it as an inferior part, and thus these humans had souls - therefore it was important to learn their languages and to come to know their myths and songs.

\section{Early institutional phase: 1850 s to 1900}

The two crucial conceptual elements of language and of culture were thus already firmly in place by the 1850s in German-language anthropology. This field gradually emerged inside and outside academia, in book publications and articles, in civil associations and in private collections, as well as inside more general university teaching programs. During the 1840 s, the time had come to further advance and popularise the collectors' side among these various activities. Upon initiatives by members of the urban elite in one of the most affluent commercial and industrial city communes anywhere in the German-speaking lands, the first anthropology museum was inaugurated in Basel in 1849. Somewhat later, Leipzig and Hamburg followed up through similar initiatives, until, by the 1870 s and 1880s, the three capital cities of Bern, Vienna and Berlin completed the vast landscapes of anthropology museums or museum departments that would remain so characteristic for the German-speaking parts of our field until this day. After its foundation, the Berlin Museum gradually emerged to become one of the world's largest (and most chaotically organised) anthropology museums, as described by Glenn Penny (e.g. 2002) and others. It continued to hold that position until its destruction during World War II.

These institutional developments between the 1840 s and the 1870 s in turn promoted organisational and conceptual consequences that are important for our contexts. Throughout the next 50 to 70 years, most professional anthropologists in the German-speaking lands would be museum experts. As a result, they had to be especially interested in material objects that could be put on display for visitors. Since manyalbeit not all —of these museum experts were armchair anthropologists, the analysis of what came to be known as 'material culture' gradually attained the status of these museum anthropologists' true intellectual and academic mission. In turn, that type of intellectual specialisation through overviews on the material sides of life enhanced methodological priorities for the dissemination of fields of cultural elements in their spatial ranges of distribution. A self-understood by-product of these professional and 
methodological constellations between the 1850s and the 1920s was that the majority of German-speaking armchair anthropologists at their home museums sought to establish and maintain well-functioning, smooth interactions with their networks of correspondents out in the field. Of course, missionaries were among the most preferred correspondents whenever they stayed on for longer periods than others, and if they spoke local languages better than other potential correspondents.

By the 1860 s, a fairly stable and coherent conceptual and organisational frame of reference was operating. In that frame of reference, out of museum practices the two notions of 'material culture' and of 'space' had been added to the conceptual priorities for 'language' and 'culture', as inherited from Herder and the Humboldts. The conceptual result, as outlined in Figure 2.2, would identify any particular culture first of all as the interplay (by means of language) between 'material culture' and 'mental culture'. That local examination of particular ethnographic examples, however, always should go hand in hand with a wider regional examination of the spatial distribution of similarities and differences among this and all other cases under scrutiny. In consequence, such spatial analyses of diversities and parallels would allow insights into those cases that might be directly related to each other, and those with less affinity. Once these relationships in space were established, it was expected to be possible to move on towards elaborating relative chronologies across (pre-)historical times. A very similar conceptual frame would also become part of the young Franz Boas's training at the Berlin Museum a few decades later. Yet it had existed before as a largely unquestioned set of priorities of interest, as Han Vermeulen (2015) has shown in his recent volume Before Boas. The conceptual frame served as a roadmap for fieldwork that the museum expert and armchair anthropologist would communicate in implicit or explicit ways to their correspondents out in the field. Whether or not those correspondents were missionaries and whether or not they had already acquired some ethnographic instructions or training units, they were expected to focus on these four or five topical fields; as was befitting for an epistemological orientation of particularism, a primary emphasis was put on exploring cultural and linguistic specificities within and among one smaller or larger group or subgroup in its particular dimensions. If time and opportunity allowed, exploring similarities and differences between this and neighbouring groups or subgroups in space came next. In addition to representing a rather clear-cut and straightforward set of ethnographic priorities, this frame of reference communicated a number of additional advantages to the missionaries in the field. 

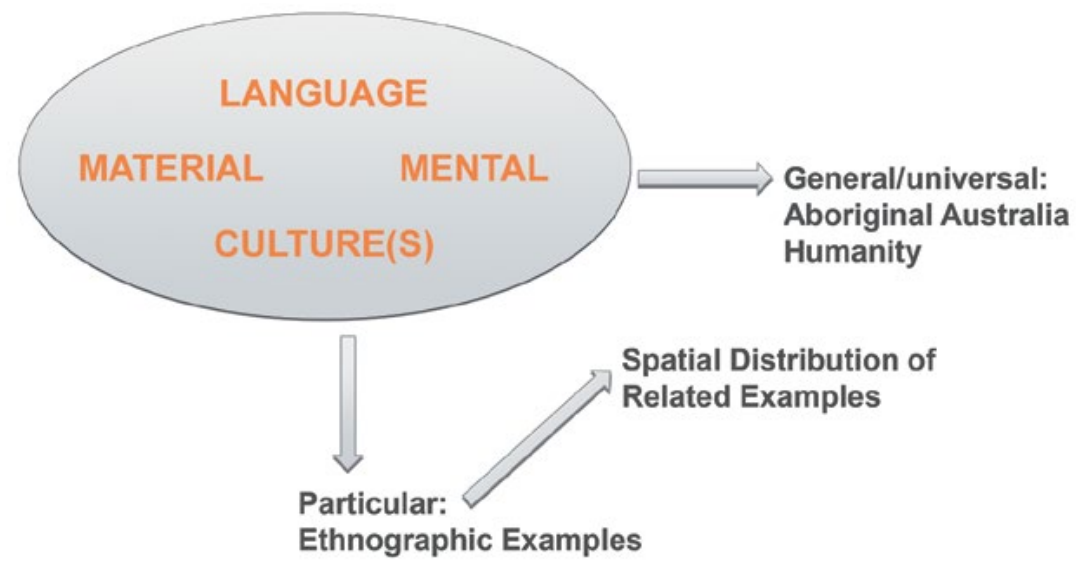

Figure 2.2 The conceptual framework that had emerged by the $1860 \mathrm{~s}$.

Source: A. Gingrich and E. M. Knoll.

First, it upgraded and supported some of the activities the missionaries were committed to pursue anyhow, such as learning and practising the local language and exploring its relation to the local conceptual, mental and spiritual world, including its myths and rituals. Second, the same frame of reference conspicuously avoided such themes as gender, sex, marriage and kinship. That, again, was compatible with the missionaries' own priorities - since, to an extent, they were merely interested in these more sensitive matters to change them as rapidly as possible into other practices, which, as they saw it, were closer to those eternal values in which they believed. It also should be said that most armchair anthropologists in the German-language zones supported views that were not too far away from that-namely, views on the nuclear family's basic eternal existence, especially so after a certain Heinrich Schurtz at the Hamburg Museum had published his volume on Altersklassen und Männerbünde (Age Classes and Male Associations) in 1902. ${ }^{4}$ That was a very popular booklet in many ways but anti-evolutionist in this particular regard, emphasising women's alleged timeless immobility in privacy in contrast to men's eternal socialising mobility in public. So the armchair anthropologists at home also were not really systematically interested in exploring social variations of gender relations or in understanding the diversities of sexual life and marriage or kinship ties, but, instead, they subsumed most

4 The book was subsequently used in conservative and even Nazi political propaganda as 'evidence' of women's allegedly timeless mission to primarily take care of the household and children. It is perhaps for this very reason that it is freely available online. See: archive.org/details/ altersklassenun00schugoog. 
of that under the heading of terminology and language. Third, that loose yet fairly straightforward frame of reference (Figure 2.2), with its basic underlying idea that Aborigines were humans with souls, did envision Aboriginal Australia as part of 'general' (or universal) humanity, albeit with 'particular' features and characteristics to be determined.

By and large, the museum expert at home and the missionary out in the field were thus both interested in intersecting and related topics, which could be organised as guiding priorities by that conceptual frame of reference for further implementation and exploration on the ground. In many ways, that frame was indeed curiosity driven, and, simultaneously, it was inspired by basic convictions about Aboriginal people being humans with souls and dignity.

My example to illustrate this general point comes from several years later-namely, from 1912. It concerns the Hermannsburg Lutheran missionary Oskar Liebler, to be seen next to his wife, who is sitting on a camel (see Plate 2.1). Liebler was a contemporary of Carl Strehlow, and was responsible for acquiring significant ethnographic elements that are in part stored or displayed in the South Australian Museum collection. In 1912, he had compiled a fairly large set of Aboriginal objects in Central Australia. The other part of the collection was transported to Berlin, and dedicated as a personal gift for Emperor Wilhelm II. The Kaiser ordered that this gift should be passed on to the Hamburg Museum, where it continues to represent a core portion of that museum's Australian collection-in fact, one of the largest of its kind in Germany to this day. Now, if we try to find out more about Liebler's ethnographically relevant papers it turns out that many of them are of course in Australia, but quite a significant amount are in German archives. Some of them are part of the Hamburg Museum collection, meticulously putting each single object into wider contexts. Others, however, are part of the archives of Liebler's Lutheran mission, which today has its central offices in Bavaria. There the relevant 'Findbuch' - that is, the archival orientation guide—informs us (see Plate 2.1) about his reports and letters back home. They contain highly interesting ethnographic materials, which some experts on Central Australia have analysed to a limited extent. There is still work to be carried out in this regard. As for methodology and ethnography, Liebler's expert contact was usually the Hamburg Museum director Georg Thilenius, born in 1868 and a lifelong armchair anthropologist and colonial strategist. Thilenius maintained a close and continuous correspondence with his old colleague Franz Boas until they broke in 1933 because of Thilenius's 
support for Hitler (Fischer 1990; Geisenhainer 2002: 46-50; Mischek 2002: 29, notes 6 and 8, cf. also pp. 30-6). Yet the point here is that, as a leading figure in German anthropology before and after the Great War, Thilenius was a fairly typical empirical diffusionist in his time, with close ties to Boas-and, as we shall see, empirical or secular diffusionism was one of the trajectories that came out of the stable frame of reference that has been discussed here. Beyond illustrating several of the above points, Liebler's example also demonstrates that, from the perspective of a historical anthropology of Australia, some of the more ethnographically interesting letters and reports by these missionaries-cum-ethnographers still wait to be examined and assessed by German-speaking PhD students and other research projects that could be supported by Australian and German, Austrian or Swiss institutions.

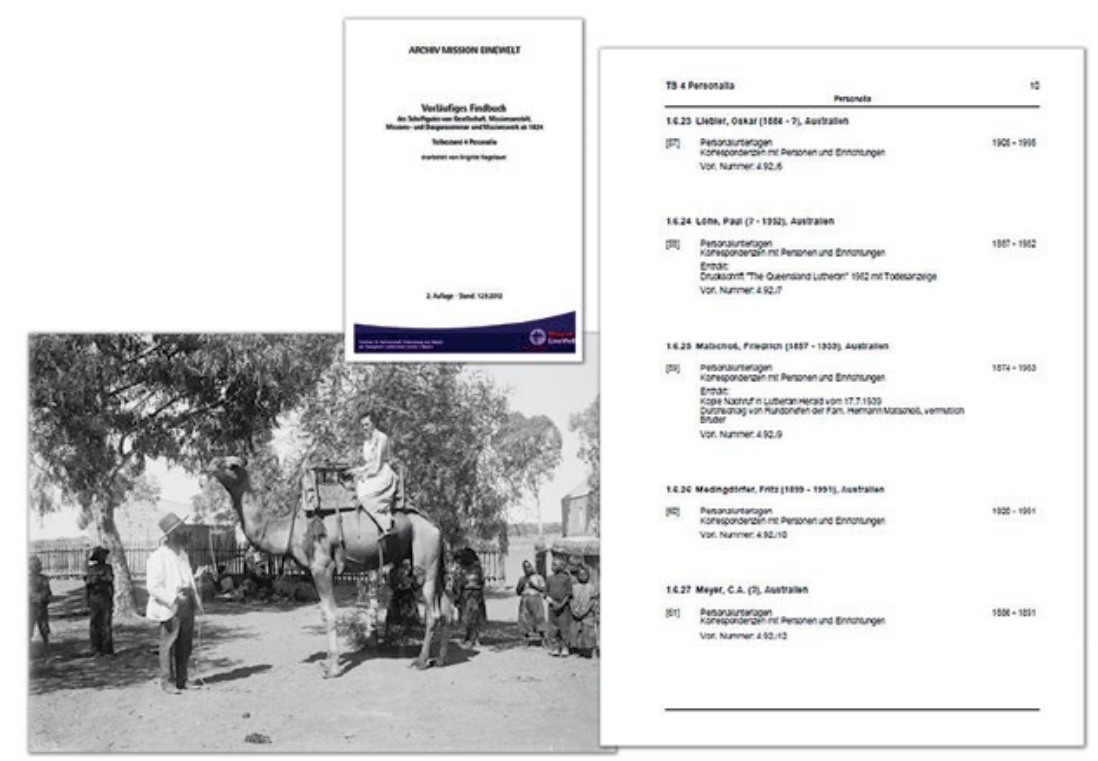

Plate 2.1 Oskar Liebler of Hermannsburg Mission and his 'Findbuch'. Source: National Library of Australia, nla.pic-vn6157043-v.

\section{Main trajectories before and after 1900}

The Prussian-led German unification process was completed in 1871; the Austro-Hungarian monarchy was formally installed in 1867; Swiss neutrality simultaneously consolidated for Europe's only republic at the time. As the nineteenth century's last quarter set in, the German-speaking 
lands had attained those political forms that would last until at least 1918. Germany, as a newly incoming colonial competitor, was also quick to establish its colonial presence in Africa, Oceania and elsewhere. Academic anthropology continued to be concentrated largely in those many major and minor museums of the German-language zone, but now they became linked to neighbouring universities and to their teaching and training programs. Together with that, imperial state interests, in contrast to civil commercial interests prevailing since the 1840 s, attained increasing influence in the field.

The German Melanesian expedition is a case in point. For the purpose of these expeditions and beyond them, biological anthropologists claimed their own field's increasing relevance. In fact, the small Berlin-Vienna Melanesian expedition of 1904-06 under Rudolf Pöch also had a brief sojourn (in 1905) and investigation series of less than four months in the Sydney area of New South Wales, in addition to their main sojourn in New Guinea's Kaiser Wilhelm's territory. For Pöch $(1915,1916)$, the ensuing publications, including his analysis of a Tasmanian skull in Vienna, were promoting his career as Vienna's leading physical anthropologist at the time and as a contributor to proliferating racist theorising on the features and qualities of what he classified as primitive races. ${ }^{5}$

For some time, ethnography and physical anthropology had understood themselves and each other as closely cooperating fields, such as during the Virchow and Bastian era at the Berlin Museum since its foundation. Many ethnographers trained by Virchow and Bastian received their first degrees in the natural sciences, such as Franz Boas, but also Erhard Eylmann (see Merlan, Chapter 11, this volume). In fact, Eylmann, as one of the very first trained German freelance ethnographers in Australia, may be seen as a close associate of the Berlin Museum's rather liberal Bastian period. Yet as influential as Bastian was in his own time, his approach to identifying 'elementary ideas' had few German-speaking followers in the next generation. On the contrary, those cultural anthropologists who came immediately after Bastian felt they had to reassert their own field against growing claims by physical anthropologists. They did so by leaving

5 Major elements of those collections of Aboriginal human remains that had been acquired during the 1850s by members of the Novara expedition, by Pöch in 1905 and by Lebzelter in 1935, continued to be in the possession of Vienna museums until most of them were officially returned to representatives of Australia in 2009 and 2011 (Krejci-Weiss 2013). On Amalie Dietrich's skeleton collections from Queensland, see Scheps (2013). 
Bastian's structural reasoning ${ }^{6}$ behind and by embracing a historicising 'Völkerkunde' more explicitly than before. Against the rising tide of fairly aggressive claims by biological anthropologists, especially after the deaths of Bastian (in 1905) and Virchow (in 1902), sociocultural anthropologists—or Völkerkundler, as they came to be called—thus had to increasingly mark their own relevance by competition.

The first theoretical and methodological schools of thought emerged in these contexts around the turn of the century in German-speaking anthropology. In many ways, these 'schools' were organic continuations of the earlier frame of reference. An exception to that was Richard Thurnwald's German variety of functionalism and economic anthropology that would emerge primarily during the 1920s. Yet all the other main schools of thought at the time were markedly anti-sociological and also anti-evolutionist in their efforts to compete not only with the biological anthropologists at home, and not only with sociocultural anthropology in the United Kingdom and France, but also with the materialist evolutionism as advocated by the labour movement, which in the Habsburg and Prussian empires was stronger than almost everywhere else.

By and large, these first trends and schools of German-speaking Völkerkunde followed various forms of historical diffusionism. Their focus continued to be on material and mental elements of culture through language, as examined in their respective spatial distribution. From here, historical conclusions would be possible through specific ways of approaching relative chronologies. In one way or another, diffusionism would remain influential in Völkerkunde until the 1950s and 1960s. I will now examine somewhat more closely these schools through their manifest forms around 1900 (see Figure 2.3).

6 Still firmly rooted in the traditions of German Enlightenment and Humboldtian relativism, which also shaped his junior museum collaborator Franz Boas, Bastian had embraced the 'psychic unity of mankind' as his key paradigm. From this point of departure, he developed his main research strategy towards identifying fairly stable 'elementary ideas' that humans had developed, according to Bastian, in line with their respective experience and linguistic skills across sociocultural and biological diversity. In his view, these elementary ideas could be identified by means of (museum) objects and their related terminology through analytical abstraction and condensation (see Koepping 1984). In view of his approaches, Bastian thus may be seen as a precursor to early structural reasoning, as elaborated shortly thereafter by Durkheim and Mauss in France. 

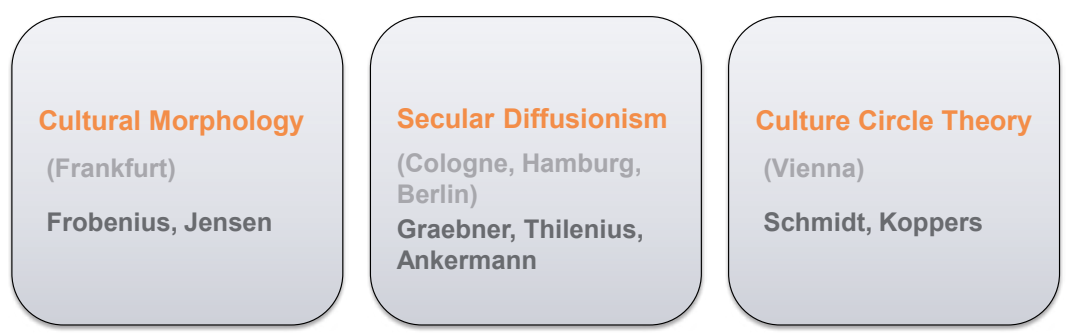

Figure 2.3 The principal schools of thought around 1900.

Source: A. Gingrich and E. M. Knoll.

In 1904 and 1905, Fritz Graebner and Bernhard Ankermann gave two famous lectures at the Berlin Museum, where, based on anthropogeographer Friedrich Ratzel's earlier reasoning, they proposed a more historically oriented Völkerkunde approach, which they called Kulturkreislehre ('culture circle' theory). Leo Frobenius had already coined that particular term, theory and methodology somewhat earlier, but distanced himself from it soon thereafter. Graebner (1911) further elaborated his own take on the historicity and relative chronology of cultural circles (or areas) by publishing his best-known book, Methode der Ethnologie. Parallel with, yet partly before, that the Westphalian-born Catholic priest Wilhelm Schmidt from the Steyl missionary order (Societas Verbi Divini: the Society of the Divine Word or SVD) had, since the 1890s, begun to establish near Vienna his own anthropological and missionary orientations. This also included his substantial and, in its time, relevant contributions to the issue of Austronesian languages (e.g. Schmidt 1899). In short, since the very first years of the twentieth century, the core elements of three diffusionist orientations existed in German-speaking anthropology that would gain some limited relevance also for the anthropology of Australia: Leo Frobenius would after the war establish his 'cultural morphology' in Frankfurt; Wilhelm Schmidt's 'Vienna school' of culture circle theory began to proliferate near Vienna (Brandewie 1990); and, as the most widespread tendency, a more secular and more empirically oriented version of diffusionism tried to remain most faithful to Graebner, who eventually (after being interned in Australia) moved to Cologne. Best known among the Graebnerians during those years were Ankermann and von Luschan in Berlin and Thilenius in Hamburg.

Some of the values and key theoretical interests pursued by these schools differed widely from each other, as briefly characterised below. The subsequent positioning of these directions and their representatives 
vis-à-vis fascism and Nazism is quite another story, largely but not entirely a political one. In fact, one does not even have to particularly sympathise with any of these directions at all, but still a minimum of critical respect would be in place since most of them in fact were serious and committed anthropologists. If only in partial and fragmentary ways, some of their insights retain some value for understanding specific problems for the historical ethnography of Australia-mostly, I would add, from my personal perspective, in empirical contexts rather than in theoretical fields.

Among these three directions, Schmidt embarked on a lifelong preoccupation with 'high gods', by picking up on a contemporary debate in British anthropology evoked by Tylor's student Andrew Lang, as will be recalled from Lang's $(1898,1899)$ arguments on Australian 'gods', as well as from Les Hiatt's careful discussion of the issue in Arguments about Aborigines (1996). In that ideological and theological focus on high gods, the Vienna school of anthropologists certainly was biased and misguided; but it has to be said to their credit that they at least helped to put the study of hunter-gatherer societies, including large portions of anthropology in Australia, into some early, empirically grounded comparative perspectives. In addition, they promoted substantial fieldwork among many foraging societies in Asia and Africa to that purpose. Schmidt also elaborated the Heidelberg economic anthropologist Ernst Grosse's distinction between more mobile 'simple' and quasi-sedentary 'complex' hunters and gatherers, and he productively pursued Eduard Hahn's early ideas about female contributions to subsistence in foraging societies half a century before feminist anthropologists would reactivate that important topic, as shown by Peter Schweitzer (2004). Among ethnographic and linguistic works grounded in Australia, the impact of Schmidt's version of anthropology is specifically present in the writings and collections of Ernst A. Worms (Society of the Catholic Apostolate, SAC) after his arrival in Australia in 1930 (see McGregor, Chapter 13, and Ganter, Chapter 14, this volume). That clear and explicit interaction between Worms and Schmidt also included a typically diffusionist theory about earlier and more recent waves of migration into Australia, by which Tasmania was seen as representing the retreat area of earlier migrations while northern Australian Aboriginal populations were viewed as representing the more recent waves of migration near the main 'entrance' of those waves.

Frobenius, on the other hand, focused in a deeply romanticising neoHerderian manner on a culture's inner being or 'Paideuma', and researched the expressions of that primarily in art, from sculpture to rock 
art. Frobenius still inspired and managed preparations for the GermanAustralian expedition of 1938, the year in which he passed away. That expedition is thus a well-known outcome of his orientation, which mostly used an anthropomorphic chronology of emergence, maturity and decay to make its main points about the cycles of cultural life. Art and its phenomenological analysis were understood as key avenues towards identifying a culture's innermost essence and its articulation in world views or cosmo-visions. The Frankfurt school is often referred to as cultural morphology ${ }^{7}$ and, in addition to Frobenius and Jensen, also included Helmut Petri and Andreas Lommel, some of whose works have been made available in English (Petri 2011; Lommel 1997). Similar to Worms and the Schmidt school, one need not accept the cultural morphologists' theoretical paradigms to respect their ethnographic results, yet to make appropriate use of their ethnographic results, it is necessary to critically understand their theoretical and methodological priorities.

The secular diffusionists such as Thilenius in Hamburg pursued Graebner's methodological program somewhat more rigidly than the other two schools, and in a manner that was more empirically grounded. In that sense one could situate them between the two other schools (also in view of the fact that the Frankfurtians were quite close to Protestant theology). Yet basically, the Graebner program (see references in Gaillard 2004: 43-4; and a useful early discussion in Lowie 1937) was also shared by the two other directions to an extent. I have already said that it was striving to document and assess the dissemination of mental and material cultures in space, to arrive at relative chronologies about what had come

7 Between 1904 and 1935, Frobenius carried out a number of famous research expeditions to various parts of sub-Saharan and North Africa that provided the ethnographic material for his most influential publications on African myth, lore, art and cosmo-vision. For Frobenius, Saharan rock art represented an especially important source for reconstructing African cultural history. Based on these empirical features and on assumptions about their migration and diffusion, he developed the methodology and theory of what he came to call 'cultural morphology' - that is, a quasi-phenomenological approach towards cultures that were seen as organisms with life cycles and a cultural 'soul' ('Paideuma', which was also the name of the journal he founded in 1938) to be accessed through key cultural features such as art, lore or myths. Frobenius had already attained some celebrity status when the Nazis came to power; they courted him during the Nazi 'peace period' until he passed away in 1938. Adolf E. Jensen, as his main disciple and successor at the Frankfurt Institute, however, soon had to face Nazi reprisals, which had partly to do with Jensen's refusal to divorce his Jewish wife (which saved her life). After 1945, Jensen therefore was seen with some justification as one of the few leading anthropologists who had remained in Germany during the war and had nevertheless maintained a fairly clean political record. That reputation also facilitated the publication of some of Jensen's work after the war in English, as part of a modestly successful attempt to gain some new respect for anthropologists in West Germany (Kohl and Platte 2006). 
earlier and what more recently. By so doing, the program distinguished more recent elements near hypothetical points of entry to the continent and older elements in remote zones of retreat, by applying non-functional criteria of form and quality as well as of quantity. If combined with modern methods of triangulation for determining age and historical background, one should not hesitate to acknowledge that some of these procedures may continue to be useful as auxiliary methodological tools for specified problems.

Before 1914, therefore, thinking about Australia was certainly developing and proliferating in productive ways inside German-speaking anthropology. The outbreak of World War I introduced a profound rupture to these tendencies.

\section{Conclusions: Transitions after 1918}

In the end, a few lines of transition may be identified that seem to have characterised the German-speaking legacies in the anthropology of Australia after the end of World War I. We know that the Great War represented an unavoidable interruption in this regard. At its outbreak, some German-speaking missionaries and anthropologists left Australia immediately, such as Felix von Luschan, while others were interned until 1918, such as Fritz Graebner. Some had to register as enemy aliens but could continue their ethnographic work if their loyalties moved in the right direction, as in Malinowski's case (in 1914, he was still a citizen of the Austro-Hungarian Empire). Still others had to register as enemy aliens-like Malinowski-even though they had Australian papers, such as Carl Strehlow, who had some of his children educated in Germany (as we know from Kenny 2013). Even more importantly, the lines of communication with offices and institutions in Germany and Austria had to be cut for years.

The relaunch of anthropological activities after 1918 was slow in Central Europe, and especially so with regard to a region such as Australia, which had been on the winners' side in the war. The three locally and regionally hegemonic schools that were outlined in the previous section took some time to re-establish themselves in new ways, which in turn allowed some room for anti-hegemonic orientations to gain ground, in contrast to their beginnings before the war. In fact, there were two especially anti-hegemonic approaches in German with some keen interest in the anthropology 
of Australia whose representatives continued with their earlier interests. On the one hand, Sigmund Freud in Vienna, in part through his and his daughter Anna's personal acquaintance with the Malinowski family, had developed a growing interest, together with Freud's disciple Géza Róheim, in understanding Aboriginal lives, rituals and, of course, 'dreaming' through psychoanalysis (see Morton, Chapter 8, this volume). On the other hand, across all major cities of the German-language zone, a second and third generation of left-leaning intellectuals inspired by the work of Marx and Engels developed an immense theoretical interest in the non-state and non-scriptural sides of Australian Aboriginal societies. This was addressed by Rosa Luxemburg in her texts written before and during the Great War (Luxemburg 1975: 624-34), by Friedrich Engels's previous associate Heinrich Cunow at the Berlin Museum during the 1920s and early 1930s (Ulrich 1987), by the young Karl August Wittfogel (1970:488-92) in his early text sections on Australia and by Paul Kirchhoff (Gray 2006), who studied with Cunow. From that spectrum, there was indeed a multilayered Marx-inspired anthropological interest inside and around the German labour movement that would in some ways resurface after 1945 in those East German contexts that were to host Fredrick Rose (Monteath and Munt 2015), from the 1950s onwards in East Berlin. ${ }^{8}$

The 15 pre-Nazi years after 1918 and the subsequent six Nazi prewar years feature a few significant changes with regard to the anthropology of Australia, if compared with what has been discussed for the time before 1914. Some of these changes are indicated by the three main elements of illustration (Figure 2.4). First, some of the missionaries-cumethnographers with a background in German continued. Although this occurred on a smaller scale, it also included new arrivals such as Ernst A. Worms (SAC) in 1930. These missionaries were somewhat less welcome inside Australia after the experience of the Great War, while they also received far less support from those weakened parts of German-speaking Europe that had lost that war.

8 Let it be noted at least in passing that those East German contexts included some interesting archival studies in Australian historical ethnography, among them most notably Helmut Reim's (1962) analysis of Australian insect food. 


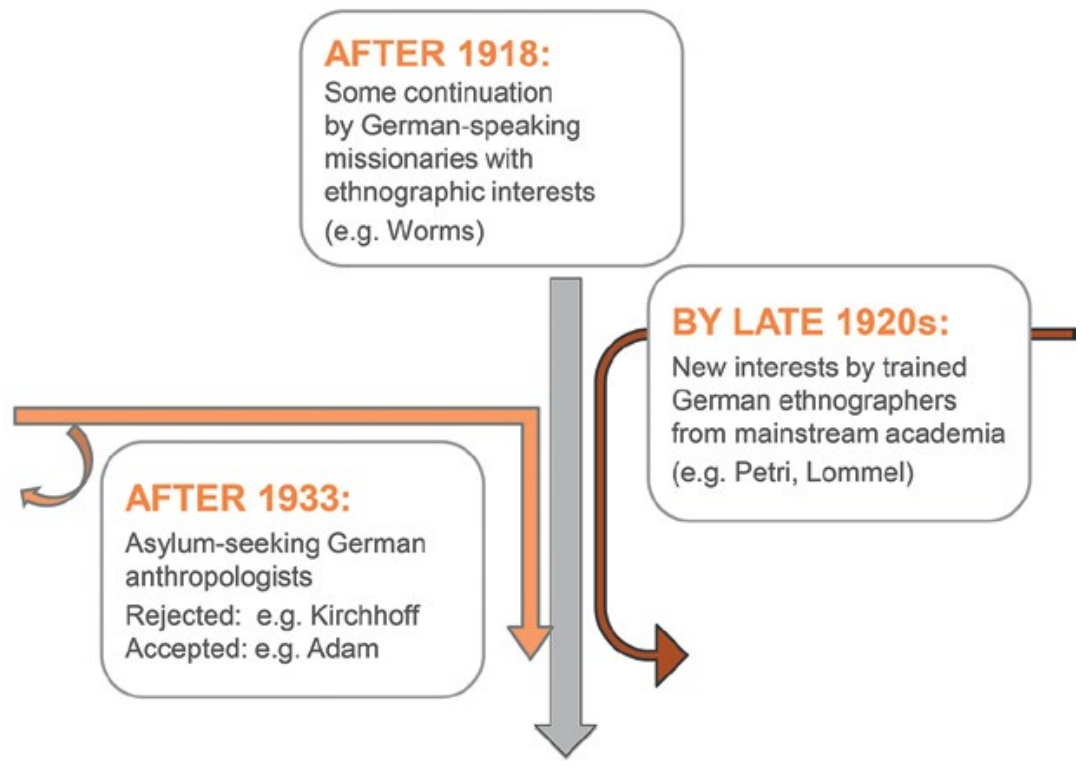

Figure 2.4 The three main schools post-1918.

Source: A. Gingrich and E. M. Knoll.

Second, from the late 1920s until the Frobenius Expedition of 1938, a new, small but relevant sequence of interventions set in from trained mainstream ethnographers from German-speaking academia-some of whom had no political interests in mind while others were at least partially involved with the rising forces of Nazism. That element is perhaps best known through the publication and translation of some of the relevant books - that is, by Lommel and Petri. ${ }^{9}$

Third, after the early 1930s, some of those German-speaking anthropologists who were fleeing from Nazism were seeking asylum in Australia. Several were rejected, such as Paul Kirchhoff, who eventually made it to Mexico. Quite a few were accepted, however, such as legal anthropologist Leonhard Adam (1944, 1954; Sloggett 2015), whose papers at his new Melbourne home institution might still deserve a fair assessment today.

9 In addition, a number of doctoral theses were submitted during the Nazi years, discussing various aspects of Australian Aboriginal ethnographic materials from local museums and archival sources in German. Two examples from the University of Vienna's Völkerkunde (Ethnology) Institute from 1940 were Frank's (1940) study of material means of communication among Aboriginal societies and Fischer-Colbrie's (1940) thesis on various types of traditional Australian weapons. 
To sum up, these transitions after 1918 already indicated that the end of an era was gradually approaching. It would come about with World War II and its aftermath. Erich Kolig (Chapter 15) and Nicolas Peterson (Chapter 18) discuss other aspects of that final phase in this volume. We may therefore conclude with the hypothesis that the three or four decades after 1918 represented the discontinuous and contradictory transition phase that put an end to the entire period and to those sets of influences under scrutiny here.

In such a perspective, the century from the 1850 s to the 1950s included many diverse interactions between German-speaking and Australian anthropology. What was to an extent hegemonic on the continental European side of this twisted and broken interrelation often was deviant or marginal on the Australian side, including significant counterexamples. Some of these interactions were more of a methodological orientation while others are worth remembering or even retrieving today, if primarily for their historical and ethnographic value. At any rate, these sources, narratives and records need not be glorified or idealised, but they also can no longer be flatly ignored. Critical and sober assessment of them in context is quite sufficient and, in fact, is long overdue for making use of the ethnographic harvest of evidence and the interpretations included, with all their limits, but also in view of their richness and potential. A lot of work remains to be carried out to that purpose.

\section{References}

Adam, L. 1944. Has Australian Aboriginal art a future? Angry Penguins [Australian Journal of Literature and Art, Adelaide University Arts Association]: 42-50.

Adam, L. 1954 [1940]. Primitive Art. 3rd edn, rev. \& enlarged. Baltimore: Penguin.

Brandewie, E. 1990. When Giants Walked the Earth: The life and times of Wilhelm Schmidt, SVD. Volume 44. Fribourg, Switzerland: Studia Instituti Anthropos.

Darragh, T. A. and Fensham, R. J. (eds). 2013. The Leichhardt Diaries: Early travels in Australia during 1842-1844. Brisbane: Queensland Museum. 
Fischer, H. 1990. Völkerkunde im Nationalsozialismus: Aspekte der Anpassung, Affinität und Behauptung einer wissenschaftlichen Disziplin. Berlin and Hamburg: Dietrich Reimer.

Fischer-Colbrie, M. 1940. Speere, Speerschleudern und Keulen der Parnkala (Süd-Australien). Doctoral thesis. Institut für Völkerkunde, University of Vienna, Vienna.

Frank, A. 1940. Botenstäbe und Wegzeichen in Australien. Doctoral thesis. Institut für Völkerkunde, University of Vienna, Vienna.

Gaillard, G. 2004 [1997]. The Routledge Dictionary of Anthropologists. London and New York: Routledge.

Geisenhainer, K. 2002. 'Rasse ist Schicksal': Otto Reche (1879-1966)_ ein Leben als Anthropologe und Völkerkundler. Leipzig: Evangelische Verlagsanstalt.

Gingrich, A. 2005. Ruptures, schools and nontraditions: Re-assessing the history of sociocultural anthropology in German. In One Discipline, Four Ways: British, German, French, and American anthropology, (eds) F. Barth, A. Gingrich, R. Parkin and S. Silverman, pp. 61-153. Chicago: University of Chicago Press.

Graebner, F. 1911. Methode der Ethnologie. Heidelberg: Winter.

Gray, G. 2006. The 'ANRC has withdrawn its offer': Paul Kirchhoff, academic freedom and the Australian academic establishment. Australian Journal of Politics and History 52(3): 362-77. doi.org/ 10.1111/j.1467-8497.2006.00424.x.

Hiatt, L. R. 1996. Arguments about Aborigines: Australia and the evolution of social anthropology. Cambridge: Cambridge University Press.

Johler, R., Marchetti, C. and Scheer, M. (eds). 2010. Doing anthropology in wartime and war zones: World War I and the cultural sciences in Europe. Transcript. Bielefeld, Germany.

Kenny, A. 2013. The Aranda's Pepa: An introduction to Carl Strehlow's masterpiece Die Aranda- und Loritja-Stämme in Zentral-Australien (1907-1920). Canberra: ANU E Press. 
Koepping, K.-P. 1984. Adolf Bastian and the Psychic Unity of Mankind: The foundations of anthropology in nineteenth-century Germany. Brisbane: University of Queensland Press.

Kohl, K.-H. and Platte, E. (eds). 2006. Gestalter und Gestalten: 100 Jahre Ethnologie in Frankfurt am Main. Frankfurt and Basel: Stroemfeld.

Krejci-Weiss, E. 2013. Abschied aus dem Knochenkabinett: Repatriierung als Instrument kultureller und nationaler Identitätspolitik am Beispiel österreichischer Restitutionen. In Sammeln, Erforschen, Zurückgeben? Menschliche Gebeine aus der Kolonialzeit in akademischen und musealen Sammlungen, (eds) H. Stoecker, T. Schnalke and A. Winkelmann, pp. 447-76. Berlin: Ch. Links Verlag.

Lang, A. 1898. The Making of Religion. London: Longmans, Green \& Co.

Lang, A. 1899. Australian gods: A reply. Folk-Lore 10: 1-46. doi.org/ 10.1080/0015587X.1899.9720479.

Lommel, A. 1997. The Unambal. Canarvon Gorge, Qld: Takarakka Nowan Kas Publications.

Lowie, R. H. 1937. The History of Ethnological Theory. New York: Farrar \& Rinehart.

Luxemburg, R. 1975 [1925]. Einführung in die Nationalökonomie. In Gesammelte Werke. Volume 5, pp. 524-778. Berlin: Dietz Verlag.

Mischek, U. 2002. Leben und Werk Günter Wagners (1908-1952). Veröffentlichungen des Instituts für Ethnologie der Universität Leipzig, Reihe Fachgeschichte, Band 2. Gehren, Germany: Escher.

Monteath, P. and Munt, V. (eds). 2015. Red Professor: The Cold War life of Fred Rose. Adelaide: Wakefield Press.

Müller, F. 1867. Reise der Oesterreichischen Fregatte Novara um die Erde, Linguistischer Theil [The journey of the Austrian Novara around the World, Linguistic Part]. Wien: Kaiserliche Akademie der Wissenschaften. 
Müller, F. 1868. Reise der Oesterreichischen Fregatte Novara um die Erde, Anthropologischer Theil, 3. Abtheilung; Ethnographie (auf Grund des von Dr. Karl v. Scherzer gesammelten Materials) [The journey of the Austrian Novara around the World, Anthropological Part/Volume/ Section]. Wien: Kaiserliche Akademie der Wissenschaften.

Müller, F. 2004 [1882]. Grundriß der Sprachwissenschaft. Volume 2: Die Sprachen der schlichthaarigen Rassen. 4 vols. Hildesheim, Germany: Olms [Vienna: Hölder].

Penny, G. H. 2002. Objects of Culture: Ethnology and ethnographic museums in imperial Germany. Chapel Hill, NC: University of North Carolina Press.

Penny, G. H. and Bunzl, M. (eds). 2003. Worldly Provincialism: German anthropology in the age of empire. Ann Arbor: University of Michigan Press.

Petri, H. 2011. The Dying World in Northwest Australia. Perth: Hesperian Press.

Pöch, R. 1915. Studien an Eingeborenen von Neu-Südwales und an australischen Schädeln. Mitteilungen der Anthropologischen Gesellschaft in Wien 45: 12-94.

Pöch, R. 1916. Ein Tasmanierschädel im kk. Naturhistorischen Hofmuseum: Die anthropologische und ethnographische Stellung der Tasmanier. Mitteilungen der Anthropologischen Gesellschaft in Wien 46: 37-91.

Reim, H. 1962. Die Insektennahrung der australischen Ureinwohner. Berlin: Akademie-Verlag.

Scheps, B. 2013. Skelette aus Queensland: Die Sammlerin Amalie Dietrich. In Sammeln, Erforschen, Zurückgeben? Menschliche Gebeine aus der Kolonialzeit in akademischen und musealen Sammlungen, (eds) H. Stoecker, T. Schnalke and A. Winkelmann, pp. 130-45. Berlin: Ch. Links Verlag.

Schmidt, W. 1899. Die sprachlichen Verhältnisse Oceaniens (Melanesiens, Polynesiens, Mikronesiens und Indonesiens) in ihrer Bedeutung für die Ethnologie. Mitteilungen der Anthropologischen Gesellschaft in Wien 29: $245-58$. 
Schurtz, H. 1902. Altersklassen und Männerbünde: Eine Darstellung der Grundformen der Gesellschaft. Berlin: Reimer.

Schweitzer, P. 2004. No escape from being theoretically important: Hunter-gatherers in German-language debates of the late nineteenth and early twentieth centuries. In History, Archaeology, and Anthropology, (ed.) A. Barnard, pp. 69-76. Oxford: Berg.

Sloggett, R. 2015. 'Has Aboriginal art a future?' Leonhard Adam's 1944 essay and the development of the Australian Aboriginal art market. International Journal of Cultural Studies 18(2): 167-83. doi.org/ $10.1177 / 1367877913515871$.

Ulrich, M. 1987. Heinrich Cunow (1862-1936): Sein ethnologisches Werk vor dem Hintergrund der Persönlichkeit, der Zeitgeschichte und der wissenschaftlichen Traditionen. Doctoral dissertation. University of Vienna, Vienna.

Vermeulen, H. 2015. Before Boas: The genesis of ethnography and ethnology in the German Enlightenment. Critical Studies in the History of Anthropology. Lincoln: University of Nebraska Press.

Wittfogel, K. A. 1970 [1932]. Die natürlichen Ursachen der Wirtschaftsgeschichte. Archiv für Sozialwissenschaft und Sozialpolitik 67. Vols 4, 5 and 6. Frankfurt: Junius.

Zammito, J. H. 2002. Kant, Herder, and the Birth of Anthropology. Chicago: University of Chicago Press. 
This text is taken from German Ethnography in Australia, edited by Nicolas Peterson and Anna Kenny, published 2017 by ANU Press, The Australian National University, Canberra, Australia.

dx.doi.org/10.22459/GEA.09.2017.02 